TINJAUAN PUSTAKA

\title{
Manajemen Transfusi Perioperatif Pada Pasien Bedah Jantung Dewasa Dengan
}

\author{
Perioperative Transfusion Management in Adult Cardiac Surgery with \\ Ornella Widyapuspita $\varpi^{*}$, Cindy Elfira Boom* \\ * Departemen Anestesi dan Perawatan Intensif Pasca Bedah RS Pusat Jantung Nasional, Harapan Kita \\ $\triangle$ Correspondence/ Korespondensi : ornella.wp@gmail.com
}

\begin{abstract}
Cardiac surgery is a common procedure in cardiac surgeries, consuming around 10-20\% of total blood transfused. It is estimated that approximately 60-70\% of these are transfused in the perioperative period. Cardiopulmonary bypass machine is an important machine that have been used for more than 60 years. This machine help a heart surgeon getting a steady and clean area for surgery. In coagulation context, the use of CPB machine caused hemodilutional anemia because the large amount of fluids used for priming, which then increased the need of blood transfusion. A few studies showed that allogeneic transfusion are associated with higher morbidities such as infection, acute kidney injury, acute hemolytic reaction, allergic reaction, acute lung injury, fluid overload, and mortality. The use of allogeneic transfusion can be reduced by applying restrictive transfusion protocol, autotransfusion method, giving errhytropoietin, antiplatelet and antifibrinolytic. An effective and rational blood transfusion management will reduce mortality and morbidity significantly.
\end{abstract}

Keywords: autotransfusion, cardiopulmonary bypass machine, hemodilutional anemia.

\begin{abstract}
ABSTRAK
Transfusi darah umum dilakukan pada pasien bedah jantung, mencakup 10-20\% dari total transfusi darah yang diberikan. Diperkirakan $60-70 \%$ pemberian transfusi terjadi selama periode perioperatif. Pemintasan jantung paru menggunakan mesin pintas jantung paru/ cardiopulmonary bypass (CPB) machine merupakan teknik penting yang telah digunakan selama lebih dari 60 tahun. Mesin ini membantu dokter bedah jantung mendapatkan area kerja yang tidak bergerak dan bersih. Dalam konteks koagulasi, pemakaian mesin CPB akan mengakibatkan timbulnya anemia hemodilusi akibat priming, sehingga seringkali memerlukan transfusi darah.Beberapa penelitian menunjukkan keterkaitan antara transfusi alogenik terkait dengan peningkatan morbiditas seperti infeksi, cidera ginjal akut, reaksi hemolitik akut, reaksi alergi, cidera paru, kelebihan cairan, dan peningkatan mortalitas.Pemberian transfusi alogenik dapat dikurangi dengan protokol transfusi restriktif, penggunaan metode autotransfusi, pemberian eritropoetin (EPO), antiplatelet, dan antifibrinolitik. Manajemen transfusi yang tepat dan rasional selama periode perioperatif bedah jantung dapat menurunkan mortalitas dan morbiditas secara signifikan.

Volume VIII, Nomor 3, Tahun 2016

Kata Kunci: anemia

Terakreditasi DIKTI dengan masa berlaku 3 Juli 2014 - 2 Juli 2019




\section{PENDAHULUAN}

Mesin pintas jantung paru/ cardio pulmonary bypass (CPB) merupakan alat bantu operasi jantung yang telah digunakan secara luas selama lebih dari 60 tahun. Mesin ini menyederhanakan operasi jantung dengan mewakilkan fungsi jantung, sehingga jantung bisa berhenti berdetak dan kosong tanpa darah. Akan tetapi, penggunaan mesin ini tentu memiliki beberapa efek samping terhadap tubuh pasien, salah satunya adalah anemia dilusional. ${ }^{1}$

Transfusi darah umum dilakukan pada pasien bedah jantung, mencakup $10-20 \%$ dari total transfusi darah yang diberikan. Diperkirakan 60$70 \%$ pemberian transfusi terjadi selama periode perioperatif. Di Amerika, kurang lebih 14 juta unit PRC dikumpulkan dan 11 juta di antaranya ditransfusikan ke 3,4 juta orang per tahun. $^{2}$

Selama operasi jantung, gangguan hemostasis dan perdarahan paska operasi juga seringkali terjadi, sehingga menyebabkan anemia paska operasi yang mencapai 44\% kasus. Menurut beberapa literatur, penurunan $1 \mathrm{mg} / \mathrm{dL}$ hemoglobin terkait dengan peningkatan kejadian kardiovaskular sebesar $13 \%$ dan peningkatan mortalitas sebesar 22\%, sedangkan perdarahan besar terkait dengan peningkatan mortalitas hingga delapan kali lipat. $^{3}$

Alasan utama pemberian transfusi perioperatif adalah berdasarkan pengamatan bahwa anemia merupakan faktor risiko independen terhadap tingkat kesakitan dan kematian paska operasi jantung, dan transfusi sel darah merah dapat menguntungkan sekelompok pasien yang mengalami gejala hipoperfusi jaringan. Akan tetapi, transfusi alogenik memiliki kaitan tinggi dengan angka kesakitan dan kematian pada pasien kritis, dan terdapat peningkatan bukti kaitan antara transfusi sel darah merah dan komplikasi infeksi, gangguan sistim jantung dan pernapasan, perpanjangan waktu rawat inap, serta mortalitas paska operasi jantung. ${ }^{4}$

Tinjauan ini dibuat untuk meningkatkan pengetahuan pembaca mengenai anemia dilusional dalam pemakaian mesin CPB pada operasi jantung, indikasi transfusi, efek samping, risiko terkait transfusi darah alogenik serta menyediakan pedoman klinis singkat dan alternatif yang ada untuk mencegah anemia akut perioperatif berdasarkan literatur yang ada.

\section{TINJAUAN PUSTAKA \\ RHEOLOGI DARAH}

Kunci utama dalam menentukan iskemia adalah keseimbangan global antara hantaran oksigen/ oxygen delivery $\left(\mathrm{DO}_{2}\right)$ dan konsumsi oksigen $\left(\mathrm{VO}_{2}\right)$. Rasio antara keduanya disebut rasio ekstraksi oksigen, dan umumnya berkisar antara 20-30\%. ${ }^{5}$ Saat hematokrit mencapai level $<25 \%$, kompensasi curah jantung untuk 
anemia dilusional akan kepayahan, dan $\mathrm{DO}_{2}$ mulai menurun, tetapi $\mathrm{VO}_{2}$ tidak berubah. Saat ketersediaan $\mathrm{O}_{2}$ menjadi terbatas, $\mathrm{VO}_{2}$ menjadi lebih tergantung pada $\mathrm{DO}_{2}$. Akan ada saatnya $\mathrm{DO}_{2}$ sudah tidak sanggup mengikuti permintaan $\mathrm{VO}_{2}$, hal ini dikenal sebagai $\mathrm{DO}_{2}$ kritikal ( $\left(\mathrm{DO}_{2 \mathrm{CRIT}}\right)$, dan secara tidak langsung mengindikasikan onset hipoksia jaringan. Level Hct $<25 \%$ juga merupakan penanda batas fisiologis anemia dilusional. ${ }^{5,6}$

Perlu diingat bahwa pada mayoritas pasien, terdapat margin yang lebar di antara $\mathrm{VO}_{2}$ dan $\mathrm{DO}_{2}$, yang berarti $\mathrm{VO}_{2}$ tidak terpengaruh dan tetap stabil walaupun terdapat penurunan $\mathrm{DO}_{2}$ dalam kondisi anemia yang bervariasi. $\mathrm{DO}_{2}$ merupakan fungsi dari curah jantung (CO) dan kandungan oksigen arteri $\left(\mathrm{CaO}_{2}\right)^{5}$

$$
\mathrm{DO}_{2}=\mathrm{CO} \times \mathrm{CaO}_{2} \text {. }
$$

Oksigen yang dibawa dalam darah dari paru terbagi dalam dua bentuk, satu terikat dengan hemoglobin eritrosit $(\mathrm{Hb})$, dan yang lain terlarut dalam plasma. Oleh karena itu, dapat disimpulkan bahwa pada pasien anemia, peningkatan konsentrasi $\mathrm{Hb}$ ([Hb]) melalui transfusi dapat meningkatkan $\mathrm{DO}_{2}$, yang akan memastikan terjaganya keseimbangan antara $\mathrm{DO}_{2}$ dan $\mathrm{VO}_{2}$, sehingga dapat mencegah atau memperbaiki iskemia. ${ }^{5}$

Logika proses ini mengakibatkan tingginya tingkat transfusi sel darah merah/ packed red cell (PRC), akan tetapi, yang terjadi pada kenyataannya berbeda. Walaupun transfusi PRC selalu terkait dengan peningkatan $[\mathrm{Hb}]$ dan seringkali meningkatkan $\mathrm{DO}_{2}, \mathrm{VO}_{2}$ tidak selalu meningkat, dan iskemi jarang membaik. $^{6}$

Darah yang keluar sebaiknya digantikan terlebih dahulu dengan cairan kristaloid dan/atau koloid. Peningkatan dilusi dari massa eritrosit sirkulasi akan menurunkan [Hb], hematokrit dan $\mathrm{CaO}_{2}$ secara eksponensial. Prinsip hemodilusi normovolemik ini mungkin dapat menguntungkan karena eritrosit lebih mudah masuk ke sirkulasi mikro. Perbaikan mikrosirkulasi yang terjadi akan meningkatkan aliran balik vena dan curah jantung, utamanya dengan meningkatkan isi sekuncup, frekuensi denyut jantung dan penurunan resistensi vaskuler. ${ }^{6}$

\section{MESIN PINTAS JANTUNG-PARU (CPB)}

Pemintasan jantung paru merupakan teknik penting yang telah digunakan selama lebih dari 60 tahun. ${ }^{1}$ Mesin CPB membantu dokter bedah mendapatkan area kerja berupa jantung dalam kondisi tidak bergerak dan tanpa darah sehingga gangguan jantung dapat diperbaiki. Mesin ini merupakan komponen utama tipe sirkulasi ekstrakorporeal atau sirkulasi yang terjadi di luar tubuh.Darah umumnya masuk ke jantung melalui atrium kanan dan mengalir menuju ventrikel kanan, lalu keluar dari jantung menuju paru untuk menukar karbon dioksida dengan oksigen. Setelah keluar dari paru, darah dikirim kembali ke atrium kiri, menuju 
ventrikel kiri untuk dipompa ke aorta dan di distribusikan ke seluruh tubuh. Mesin CPB melakukan hal yang mirip, hanya saja terjadi di luar tubuh, di dalam mesin.,

Dalam mesin CPB, darah berinteraksi dengan permukaan nonendotel. Membran oksigenator membantu mengurangi aktivasi koagulasi akibat interaksi darahpermukaan. Akan tetapi, masih terjadi berbagai respon patofisiologis luar biasa yang mempengaruhi koagulasi darah terkait dengan cidera mekanik dan cidera pada jaringan. ${ }^{8}$

Mesin CPB dilengkapi dengan sebuah reservoar, tempat darah dari jantung dialirkan, sehingga tercipta lapangan operasi bebas darah untuk operasi katup dan aorta. ${ }^{7,8}$ Sirkuit ekstrakorporeal ini perlu dilakukan priming terlebih dahulu menggunakan larutan elektrolit seimbang untuk menghindari emboli udara sebelum dihubungkan ke pasien. Volume priming umumnya sekitar $30 \%$ volume darah dewasa. Hemodilusi awal bersifat proporsional terhadap rasio volume darah pasien dibanding volume priming. Hemodilusi ringan dapat mengurangi kekentalan darah dan meningkatkan aliran darah ke otak. Batasan hemodilusi dapat dilihat dari kadar hematokrit (Hct). Kadar Hct yang dapat ditoleransi selama CPB berkisar antara $<18 \%$ hingga $30 \%$ tergantung usia dan komorbid pasien. ${ }^{7}$

Dalam konteks koagulasi, terdapat variasi kemunculan mekanisme aktivasi hemostatik.
Sebagai contoh, salah satu hal yang paling pertama terjadi saat memakai mesin CPB adalah darah pasien akan bercampur dengan cairan priming berupa kristaloid atau koloid sebesar kurang lebih 1 liter. Hal ini menghasilkan efek dilusi yang turut berkontribusi pada beberapa masalah koagulasi, antara lain trombositopenia delusional (terjadi penurunan $40-60 \%$ jumlah trombosit setelah operasi). ${ }^{8}$ Umumnya, PRC dapat diberikan bersama kristaloid atau koloid sebagai cairan priming untuk menurunkan risiko hemodilusi berlebihan. $^{9}$

\section{ANEMIA AKUT PERIOPERATIF}

Anemia normovolemia akut pada pasien sadar dapat menyebabkan peningkatan fisiologis curah jantung akibat peningkatan volume sistolik dan volume jantung. Pada pasien dalam kondisi teranestesi, curah jantung hanya meningkat sebagai hasil dari peningkatan volume sistemik, oleh karena itu, adanya onset takikardia pada kondisi anemia akut merupakan indikator hipovolemia, yang harus segera diperbaiki dengan pemberian cairan kristaloid atau koloid. Pemantauan perfusi adekuat dan oksigenasi organ vital harus berdasarkan evaluasi tekanan darah arterial, laju jantung, suhu tubuh, saturasi oksigen, $\mathrm{pH}$, jumlah urin, dan sadapan elektrokardiografi (EKG), namun pada kondisi tertentu, perlu dilakukan pula evaluasi ekokardiografi, pemeriksaan saturasi oksigen vena 
campuran dan analisa gas darah. ${ }^{10}$

TRANSFUSI DARAH PERIOPERA - TIF

\section{Evaluasi Risiko Perdarahan}

Evaluasi preoperatif yang menyeluruh penting dilakukan untuk mengetahui risiko perdarahan, memprediksi kebutuhan transfusi darah yang tepat, dan untuk mengevaluasi indikasi serta kesiapan pasien dalam menerima transfusi darah. Evaluasi yang dilakukan mencakup riwayat perdarahan spontan, perdarahan setelah trauma, penggunaan antikoagulan dan anti-agregasi.Pada pasien dengan riwayat perdarahan atau dengan indikasi yang jelas (misalnya pada pasien dengan penyakit hati) diperlukan pemeriksaan lanjutan. Pemeriksaan ini disesuaikan dengan riwayat dan gejala klinis pada pasien. Evaluasi ini sebaiknya dilakukan dalam waktu yang memadai (misalnya sejak 30 hari sebelum intervensi) sehingga didapatkan informasi diagnostik yang cukup sebagaipertimbangan terapi dan tindakan yang akan dilakukan. ${ }^{10}$

Terdapat sedikitnya 6 faktor risiko perdarahan hebat pada pasien yang menjalani operasi jantung dan membutuhkan transfusi darah yang banyak: 1) usia tua 2) volume sel darah merah menurun (karena anemia atau massa tubuh yang rendah) 3) terapi antikoagulan atau antiplatelet 4) operasi darurat 5) durasi pemakaian mesin CPB yang memanjang 6) komorbid seperti gagal jantung kongestif, gagal ginjal, dan penyakit paru obstruktif kronik.
Intervensi preoperatif hanya dapat mengurangi 2 dari faktor risiko tersebut, melalui penggunaan terapi antikoagulan dan penambahan volume sel darah merah. ${ }^{11}$

\section{Indikasi Transfusi}

Titik picu transfusi merupakan istilah yang digunakan untuk mendeskripsikan kondisi dimana transfusi dianggap rasional, tanpa melihat hasil penunjang lain. Sebelum tahun 1980, pasien bedah dianggap berada dalam kondisi optimal apabila level hemoglobin $>10 \mathrm{~g} / \mathrm{dL}$ dan hematokrit $>30 \%$ (prinsip 10/30). ${ }^{12}$ Selama puluhan tahun, level ini dipercaya sebagai titik picu yang tepat untuk memulai transfusi,namun sebuah penelitian di tahun 1990 merubah aturan transfusi secara drastis, menghasilkan kecenderungan untuk melakukan transfusi di level hemoglobin yang lebih rendah. ${ }^{3}$

Sebuah penelitian baru-baru ini menyarankan strategi yang lebih restriktif terhadap transfusi PRC dengan target hematokrit sebesar 24\%. Tingkat mortalitas 30 hari dan komplikasi berat yang didapatkan kurang lebih sebesar 10\% pada kedua grup (liberal dan restriktif). ${ }^{3}$

Tanda dan gejala anemia berat (dispnea pada aktifitas, nyeri dada, letargi, hipotensi, pucat, takikardia, penurunan kesadaran) seringkali muncul saat kadar hemoglobin terlalu rendah. Gejala sesak napas saat aktifitas umumnya akan muncul saat hemoglobin turun hingga $<7 \mathrm{~g} / \mathrm{dL}$. 
Pada penelitian lain, didapatkan bahwa dengan kadar hemoglobin $6 \mathrm{~g} / \mathrm{dL}$, hanya $54 \%$ pasien mengalami gejala takikardia, 32\% mengalami hipotensi, $35 \%$ mengalami penurunan kesadaran, dan 27\% mengalami sesak napas. Pada pasien teranestesi, tentunya kita tidak bisa bergantung pada tanda dan gejala ini, sehingga seringkali terjadi keterlambatan transfusi. ${ }^{12}$

Titik picu yang aman selama pemakaian mesin CPB dapat diturunkan hingga $6 \mathrm{~g} / \mathrm{dl}$ dengan kondisi hipotermia sedang, kecuali pada pasien dengan riwayat gangguan serebrovaskular, diabetes mellitus, dan stenosis karotis. Pada kelompok pasien dengan risiko penurunan $\mathrm{DO}_{2}$ serebral dan cidera organ akhir, adalah rasional untuk menjaga kadar $\mathrm{Hb} \geq 7 \mathrm{~g} / \mathrm{dl}$. Pertimbangkan kondisi klinis pasien seperti usia, beratnya penyakit, iskemi organ akhir, fungsi jantung, status perdarahan dan data klinis laboratorium untuk mengambil keputusan jika nilai $\mathrm{Hb}>6 \mathrm{~g} / \mathrm{dl}$ saat memakai mesin CPB. ${ }^{13}$

Penelitian in-vitro dari isolat jaringan dan anemia normovolemi pada hewan menunjukkan level hemoglobin minimal dimana $\mathrm{DO}_{2}$ jaringan masih adekuat adalah 3-5 g/dL. Hemodilusi akut normovolemi hingga $\mathrm{Hb} 5 \mathrm{~g} / \mathrm{dL}$ dapat ditoleransi dengan baik tanpa tanda hipoksia jaringan. Terdapat beberapa mekanisme kompensasi yang berkontribusi menjaga kecukupan oksigenasi jaringan yang teraktivasi sebagai respon terhadap perdarahan hebat dan anemia. Mekanisme tersebut melingkupi peningkatan curah jantung, laju jantung, dan volume pompa ventrikel kiri, peningkatan rasio ekstraksi oksigen $\left(\mathrm{O}_{2}\right.$ ER), realokasi aliran darah, serta pergeseran ke kanan kurva disosiasi $\mathrm{Hb}-\mathrm{O}_{2}$. Jantung menjadi lebih dependen terhadap $\mathrm{DO}_{2}$ dibanding organ lain. Dalam keadaan normal, miokardium mengekstraksi 50\% oksigen yang dihantarkan, melebihi organ-organ lain. Peningkatan aktifitas akan meningkatkan kebutuhan $\mathrm{DO}_{2}$ ke miokardium. Dalam kondisi anemia, aliran darah ke miokardium dan fraksi ekstraksi oksigen harus ditingkatkan untuk dapat memenuhi kebutuhan jaringan. Jantung yang sehat dapat mengkompensasi hingga batas $\mathrm{Hb} 3$ atau $4 \mathrm{~g} / \mathrm{dL}$, di bawah batas itu akan terjadi iskemi miokard. ${ }^{12}$

\section{Risiko Transfusi Alogenik}

Komplikasi yang berkaitan dengan transfusi dapat dikategorikan menjadi akut atau lambat, serta infeksi dan non infeksi. Reaksi transfusi akut terjadi dalam hitungan menit hingga 24 jam paska transfusi. Sementara reaksi lambat dapat terjadi dalam hitungan hari, bulan, bahkan beberapa tahun kemudian. Kejadian infeksi paska transfusi semakin sedikit terjadi karena teknologi skrining yang semakin canggih. Namun tidak demikian dengan kejadian berbahaya non infeksi, yang tetap tinggi meskipun uji skrining yang semakin maju. Oleh karena itu pasien lebih mungkin mengalami reaksi non infeksi dibandingkan dengan infeksi paska transfusi. ${ }^{14}$ 


\section{Infeksi}

Infeksi yang berhubungan dengan transfusi semakin jarang terjadi karena teknologi skirining darah yang semakin maju. ${ }^{14}$ Meskipun transmisi agen infeksi secara langsung melalui transfusi darah alogenik cukup rendah, namun transfusi berhubungan dengan imunomodulasi yang dapat mempengaruhi risiko infeksi. Ketika pasien menerima darah dari donor, sistem imun mereka dapat bereaksi terhadap substansi yang terdapat dalam darah donor. Risiko healthcare associated infection (HAI) meningkat menjadi $17 \%$ ketika transfusi diberikan secara liberal, dan turun menjadi $12 \%$ ketika transfusi diberikan secara restriktif. Namun hal ini bergantung pada klinis pasien. Risiko infeksi menjadi kurang lebih sama pada pasien yang menjalani operasi jantung, kritis, memiliki perdarahan saluran cerna atas akut, atau bayi dengan berat badan lahir rendah. $^{15}$

\section{Cidera ginjal akut}

Risiko cidera ginjal akut menurut criteria RIFLE adalah penurunan mendadak dari fungsi ginjal yang ditandai dengan peningkatan $>50 \%$ dari kreatinin serum atau penurunan $>25 \%$ dari laju filtrasi glomerulus. Komplikasi ini umum terjadi pada pasien yang menjalani operasi jantung dengan mesin pintas jantung. Identifikasi terhadap faktor risiko cidera ginjal akut pada operasi jantung telah banyak diteliti, namun kebanyakan tidak mempertimbangkan transfusi darah perioperatif sebagai salah satu faktor risiko. ${ }^{16}$

Satu unit sel darah merah dapat disimpan selama 42 hari sebelum ditransfusi. Selama masa penyimpanan, terjadi perubahan biokimia dan morfologi yang diduga menyebabkan kerusakan organ paska transfusi. Hal ini meliputi penurunan adenosine diphosphate (ADP) dan 2,3-DPG, peningkatan lipid peroksidase, serta penurunan mekanisme yang diperantarai oleh nitric oxide (NO). Semakin lama disimpan, membran eritrosit akan mengalami perubahan ireversibel dan menjadi lebih rapuh. Selanjutnya akan terjadi hemolisis progresif, formasi mikrovesikel, serta akumulasi molekul pro inflamasi, hemoglobin bebas, dan besi. Ketahanan hidup paska transfusi juga terpengaruh. Dalam 1 jam paska transfusi, sampai $30 \%$ sel darah merah yang ditransfusi mengalami hemolisis atau dibuang dari sirkulasi oleh makrofag. Ketika terjadi hemolisis, jumlah ikatan hemoglobinbesi bebas sirkulasi akan melebihi kapasitas pengikatan besi oleh transferin. Ikatan hemoglobin-besi bebas sangat toksik bagi ginjal dan organ lain karena menyebabkan disfungsi mikrosirkulasi dengan "mengambil" NO. Besi bebas juga merupakan pro-oksidan kuat. Operasi jantung dengan mesin CPB sendiri merupakan sebuah faktor yang memperberat karena sirkulasi pada sirkuit di luar tubuh merusak eritrosit secara progresif sehingga semakin banyak ikatan hemoglobin-besi bebas 
di sirkulasi. ${ }^{16}$

\section{Reaksi hemolitik akut}

Hal ini terjadi karena sistem imun yang menghancurkan sel darah merah donor dalam 24 jam paska transfusi. Antibodi tersebut dibentuk oleh transfusi sebelumnya atau kehamilan. Hemolisis yang terjadi dapat bersifat intravaskular atau ekstravaskular, namun yang umum terjadi adalah jenis ekstravaskular. Hemolisis ekstravaskular terjadi karena sel darah merah donor yang dilapisi oleh IgG atau komplemen diserang di limfa atau hati, sementara hemolisis intravaskular merupakan bentuk hemolisis berat yang disebabkan oleh antibodi ABO. ${ }^{14}$

\section{Reaksi alergi}

Reaksi alergi bervariasi mulai dari ringan (urtikaria) hingga mengancam nyawa (reaksi anafilaktik). Reaksi alergi terjadi pada $1-3 \%$ dari transfusi darah. Reaksi anafilaktik terjadi sebagai respon dari presensitisasi terhadap berbagai jenis protein di plasma donor. Reaksi ini umumnya ditandai dengan reaksi urtikaria, namun disertai beberapa gejala lain seperti hipotensi, bronkospasme, stridor dan gejala gastrointestinal. Anti-human leukocyte antigen (HLA) antibodydan antibodi antikomplemen sering dikaitkan dengan reaksi ini, yang diperkirakan terjadi dalam 1:20.000-50.000 transfusi darah. Pencegahan terhadap reaksi alergi dapat dilakukan dengan mencuci darah merah endap untuk membuang plasma dan menghindari transfusi plasma dengan IgA pada pada pasien yang diketahui memiliki defisiensi IgA. Reaksi alergi sebaiknya dipantau dalam 15 menit pertama transfusi darah. ${ }^{14}$

\section{Transfusion-related acute lung injury (TRALI)}

TRALI merupakan edema paru non kardiogenik yang menyebabkan hipoksemia akut dan terjadi dalam 6 jam sejak dilakukan transfusi. Pasien dengan TRALI tidak memiliki faktor risiko lain terhadap cidera paru akut. Edema disebabkan oleh aktivasi system imun penerima donor terhadap antibodi anti-HLA. Netrofil yang teraktivasi juga mengeluarkan enzim proteolitik yang mengakibatkan cidera jaringan lebih jauh. Produk donor dengan kandungan plasma yang banyak dari perempuan multipara diduga berkaitan dengan TRALI, hal ini diperkuat dengan fakta bahwa mortalitas menurun secara signifikan ketika donor plasma pria diberikan secara eksklusif. ${ }^{14}$

\section{Reaksi demam non hemolitik paska transfusi}

Reaksi demam non hemolitik paska transfusi/ febrile nonhemolytic transfusion reactions (FNHTR) adalah kenaikan temperatur tubuh minimal $1{ }^{\circ} \mathrm{C}$ di atas $37^{\circ} \mathrm{C}$ dalam 24 jam paska transfusi. Demam terjadi lebih sering pada pasien dengan transfusi berulang dan pada pasien hamil. FNHTR merupakan diagnosa ekslusi yang ditetapkan setelah mengeliminasi 
penyebab lain yang dapat menyebabkan demam, seperti sepsis dan hemolisis. Beberapa mekanisme diduga menyebabkan FNHTR: pelepasan pirogen endogenik dan sitokin. Sitokinsitokin yang terlibat adalah IL-1, IL-6, IL-8, dan TNF. Dewasa ini, penggunaan leukoreduksi (filtrasi leukosit dari darah donor) telah menurunkan insidensi FNHTR. ${ }^{14}$

\section{Kelebihan Cairan Terkait Transfusi}

Kelebihan cairan yang berhubungan dengan transfusi ini merupaka akibat transfusi dalam waktu yang cepat dan melebihi kapasitas sirkulasi penerima donor. Mereka yang berisiko mengalami kelebihan cairan adalah pasien dengan penyakit kardiopulmonal, gagal ginjal, anemia kronis, bayi atau orang tua. Tanda dan gejala yang menyertai adalah takikardi, batuk, sesak nafas, hipertensi, kenaikan tekanan vena sentral, dan pulsasi yang melebar. Pada rontgen thoraks dapat terlihat kardiomegali dan edema pulmoner. Peptida natriuretik otak dapat membantu menetapkan diagnosa. Kadar peptida natriuretik otak akan meningkat secara signifikan sebagai respon terhadap tekanan yang meningkat. Terapi yang perlu dilakukan adalah diuresis untuk menurunkan volume cairan. ${ }^{14}$

\section{Reaksi transfusi tipe lambat Graft versus host reaction}

Hal ini terjadi akibat proliferasi limfosit donor menyebabkan serangan pada organ dan jaringan penerima donor. Pasien yang rentan terhadap kondisi ini adalah pasien imunokompromis atau pasien imunokompeten yang menerima transfusi dengan haplotipe HLA yang sama, misalnya donor yang merupakan anggota keluarga pasien. Gejala meliputi kemerahan, demam, diare, disfungsi hati, dan pansitopenia yang terjadi 1-6 minggu paska transfusi. ${ }^{14}$

\section{ALGORITMA TRANSFUSI}

Terdapat sebuah penelitian yang menyusun suatu algoritma pemberian transfusi berdasarkan pemeriksaan koagulasi pada pasien yang akan menjalani operasi jantung dengan mesin CPB. Melalui penggunaan algoritma tersebut, dapat dilihat adanya penurunan rasio transfusi, kecuali pada kriopresipitat. Algoritma ini diharapkan dapat meningkatkan kualitas penanganan pada pasien yang mengalami perdarahan akibat koagulopati setelah operasi jantung. ${ }^{16}$

\section{TRANSFUSI AUTOLOG / AUTO- TRANSFUSI}

Autotransfusi merupakan alternatif dari donor transfusi darah alogenik, dimana donor dan penerima ialah individu yang sama. Umumnya kriteria pengumpulan darah autolog sama dengan pengumpulan darah alogenik, yaitu mencakup pengumpulan, penyimpanan, dan kebutuhan pengolahan darah. ${ }^{17}$

Autotransfusi memiliki beberapa keuntungan seperti darah memiliki $\mathrm{pH}$ yang relatif normal, risiko 
penyakit menular lebih rendah, cepat tersedia, suhu normal, kadar kalium lebih rendah, dan dapat digunakan pada pasien yang menolak transfusi darah alogen karena keyakinan agama. Kerugian autotransfusi yaitu biaya yang lebih mahal daripada darah alogenik atau homolog, peningkatan kompleksitas dari pemberian transfusi, pengelolaan yang cermat, serta kemungkinan adanya kehilangan darah yang tidak perlu jika operasi ditunda atau transfusi tidak diperlukan. ${ }^{17}$

Pengolahan autotransfusi terdiri tiga fase, yaitu: fase pertama yang mengaplikasikan gaya sentrifugal untuk memisahkan komponen darah dari cairan; fase pencucian yang mengeluarkan stomata selular, plasma, trombosit, larutan antikoagulan, sel darah putih, faktor pembekuan yang diaktifkan; dan fase terakhir yaitu fase kosong (darah akan dipompa ke dalam kantong reinfusi). ${ }^{18}$

Pengumpulan sel darah merah dari lapangan operasi membutuhkan alat suction berlumen dua. Lumen pertama menyedot darah dan lumen yang lain menambahkan salin yang mengandung heparin ke darah yang dikumpulkan. ${ }^{17,19}$ Terdapat 2 sistem pada metode ini, yaitu 'washed' dan 'unwashed'. Pada sistim unwashed, darah ditransfusi dari penampungan yang terhubung dengan drain ke set infus dan ditransfusi tanpa menjalani proses. Darah akan mengalir melalui 2 filter, yang pertama berupa mesh dengan ukuran pori 100-200 $\mu$ untuk menahan fibrin dan makroagregat.
Filter kedua berupa mesh dengan ukuran pori $40 \mu$ untuk menahan mikroagregat. Tidak diperlukan penggunaan antikoagulan karena darah tidak mengandung fibrinogen Pada sistim washed diperlukan perlengkapan khusus untuk pengendapan darah yang telah dikumpulkan, membuang supernatant, mencuci sel darah merah dan merendamnya kembali di cairan garam fisiologis. Sistim ini lebih mahal dan membutuhkan tenaga ahli yang terlatih. ${ }^{20}$ Pencampuran dengan cairan garam fisiologis akan menghasilkan hematokrit sekitar 50-80\%. Produk darah yang dihasilkan harus segera ditransfusi dalam 6 jam. ${ }^{19}$

Penggunaan metode ini menghemat rata-rata 0.65 unit darah per pasien. Metode autotransfusi mempertahankan bentuk bikonkaf, meningkatkan viabilitas sel darah merah, 2,3-DPG, serta kadar adenosine triphosphate (ATP) dalam darah. ${ }^{19}$

Terdapat beberapa potensi komplikasi yang berhubungan dengan autotransfusi, seperti hemolisis, emboli udara, reaksi demam, koagulopati, kontaminasi dengan zat seperti obat, cairan pencuci, agen infeksi, dan pembersihan yang tidak sempurna. Hemolisis masif dapat terjadi apabila secara keliru menggunakan aqua bides untuk pencucian. Risiko komplikasi telah semakin berkurang dengan kemajuan teknologi. Autotransfusi mengeliminasi platelet dan faktor koagulasi sehingga dapat menyebabkan koagulopati. Pada kondisi kehilangan 
darah $<3$ liter, pembekuan darah pasien akan tetap normal. ${ }^{19}$

Penggunaan autotransfusi pada operasi jantung menurunkan angka transfusi produk darah hingga 37\% dan sel darah merah hingga 40\%. Metode autotransfusi tidak meningkatkan risiko mortalitas, stroke postoperatif, infark miokard, fibrilasi atrial, disfungsi ginjal, infeksi, dan perdarahan. Penurunan kadar lipid dan mikropartikel dalam darah akan menurunkan risko disfungsi neurokognitif pasca operasi. Metode autotransfusi juga mengurangi cidera pada membran kapiler alveolus dan mengurangi waktu pemakaian ventilasi mekanik. ${ }^{19}$

\section{Donasi autolog pre-operatif}

Pada metode ini, darah dikumpulkan dan disimpan sebagai unit dari seluruh darah yang belum diproses, tetapi lebih umum untuk memroses donasi ke unit plasma dan sel darah merah. Darah yang dikumpulkan dapat disimpan hingga 42 hari. Teknik ini diindikasikan untuk prosedur bedah elektif yang membutuhkan autotransfusi dan tersedia cukup waktu untuk mendapatkan satu atau lebih unit darah dengan risiko yang minimum tanpa mengakibatkan penurunan hemoglobin yang bermakna pada pasien donor. Sebagai contoh yaitu bedah ortopedik, bedah plastik dan rekonstruktif, serta bedah jantung. Kontraindikasi teknik ini yaitu bakteriemia dan infeksi lokal akut, infark miokard dalam enam bulan terakhir, angina yang tidak stabil, stenosis aorta, gagal jantung kongestif, serta hipertensi yang tidak terkontrol. ${ }^{17}$

\section{Intra-operative Blood Salvage (IOBS)}

Metode ini berupa pengumpulan dan reinfusi darah yang hilang selama dan segera setelah pembedahan. Metode ini telah umum digunakan untuk operasi bedah kardiovaskular dan ortopedik, transplantasi organ padat, dan kasus-kasus trauma. Metode ini hanya dapat digunakan pada luka yang bersih, dan tidak boleh digunakan pada pasien dengan keganasan serta adanya atau dicurigai adanya kontaminasi bakteri. Darah yang keluar dikumpulkan dari lapangan operasi dan diberi antikoagulan. Darah ini dibuat terkonsentrasi, kemudian dicuci atau disaring sebelum direinfusi untuk menghindari peningkatan risiko koagulopati dan reaksi autoimun, dan dikembalikan ke pasien. Darah tidak boleh dikeluarkan dari ruang operasi, harus diberi label yang jelas, dan harus ditransfusikan segera dan optimal dalam waktu empat jam dari akhir pengumpulan. Jika tidak dapat segera digunakan, maka darah tersebut harus segera disimpan. Teknik ini digunakan dalam berbagai prosedur bedah yaitu kardiovaskular, ortopedik, transplantasi hati, kehamilan ektopik yang tergaggu, dan trauma. ${ }^{17}$

\section{Post-operative Blood Salvage (POBS)}

Teknik ini yang paling banyak digunakan pada prosedur bedah jantung dan ortopedik. Pengumpulan umumnya dari area mediastinum serta rongga 
dada, dan ditransfusikan tanpa dicuci terlebih dahulu. Teknik ini ditujukan untuk mengumpulkan pengeluaran darah paska pembedahan, biasanya dalam waktu 24-48 jam setelah operasi pada pasien yang mengalami perdarahan aktif. Teknik ini dikontraindikasikan bila terdapat bukti infeksi atau sel-sel tumor ganas dari tempat keluarnya darah atau dalam darah yang disimpan; atau bila kehilangan darah kurang dari $50 \mathrm{~mL} /$ jam. Darah harus disaring sebelum dikembalikan pada pasien dan harus direinfusi dalam waktu enam jam dari awal pengumpulan untuk meminimalisasi proliferasi dari bakteri. Kantong darah harus diberi label nama pasien dan nomor identifikasi. ${ }^{17}$

\section{Acute normovolaemic haemodilution} (ANH)

Jenis autotransfusi ini merupakan teknik untuk mempertahankan volume dalam vaskular sebelum kehilangan darah. Hemodilusi ialah pilihan transfusi untuk pasien yang mengalami penurunan konsentrasi hemoglobin yang akut yang besar. Teknik ini mengurangi kehilangan sel darah merah karena darah yang hilang selama operasi memiliki hematokrit yang rendah. Teknik ini melibatkan pengumpulan darah pasien sekitar dua sampai empat unit dalam kantong penyimpanan yang mengandung antikoagulan pada awal pembedahan, disertai pengganti intravena dengan kristaloid atau koloid untuk mempertahankan normovolemia.
Seluruh darah pasien dapat ditransfusikan jika diperlukan. Teknik ini diindikasikan pada prosedur bedah yang diduga kehilangan darah lebih dari satu liter, sebagai contoh bedah kardiovaskular, bedah vaskular, operasi tulang belakang untuk skoliosis, dan penggantian sendi lutut atau pinggul total. Sebagai kontraindikasi yaitu pasien dengan gangguan fungsi ginjal yang tidak apat mengekskresikan sebagian besar cairan infus, bakteremia, kehamilan dengan anemia, penyakit dengan defisiensi faktor koagulasi, dan hemoglobin yang kurang dari $11 \mathrm{~g} / \mathrm{dL}$ karena hemodilusi ini akan segera menurunkan hemoglobin $1 \mathrm{~g} / \mathrm{dL}$ untuk setiap unit darah yang dikeluarkan. ${ }^{17}$

\section{TERAPI FARMAKOLOGI Eritropoetin (EPO)}

Eritropoetin adalah glikoprotein endogen yang menstimulasi produksi sel darah merah sebagai respon terhadap hipoksia jaringan dan anemia. Produsen EPO utama adalah ginjal, sehingga pada pasien dengan gangguan ginjal produksi EPO akan menurun drastis. Pemberian EPO preoperatif (ditambah dengan besi) dapat dilakukan beberapa hari sebelum operasi jantung pada pasien dengan anemia, menolak transfusi darah (seperti saksi Yehova), atau memiliki risiko tinggi terhadap anemia paska operasi. Penggunaan terapi kombinasi human recombinant EPO dan besi sebelum operasi jantung pada pasien yang anemia terbukti memberikan perkembangan yang baik pada observasi setelah operasi dan 
secara signifikan mengurangi transfusi sel darah merah. ${ }^{21,22}$

Terdapat beberapa kekhawatiran akan efek samping EPO seperti hipertensi dan trombus kardiovaskular pada penggunaan dalam jangka waktu yang lama. Namun pada beberapa penelitian tidak ditemukan peningkatan risiko trombosis setelah operasi pada pasien yang menjalani operasi penggantian katup jantung. EPO memiliki masa kerja antara 4-6 hari. $^{21,22}$

Belum banyak penelitian yang mendukung penggunaan EPO pada pasien yang diperkirakan akan kehilangan darah cukup banyak. Beberapa pertimbangan lain adalah situasi di mana produksi EPO endogen menurun, misalnya pada pasien yang mengonsumsi penghambat beta. Penghambat beta mensupresi produksi EPO endogen. Sebagai tambahan, sitokin yang distimulasi sebagai reaksi inflamasi akibat pemakaian mesin CPB akan mengurangi produksi EPO endogen. Demikian pula dengan iskemia renal. Penurunan EPO endogen perioperatif mendukung penggunaan EPO tambahan beberapa hari sebelum operasi pada pasien tertentu. ${ }^{11}$

\section{Antiplatelet}

Antiplatelet atau penghambat platelet P2Y12 adalah obat yang sering digunakan oleh pasien dengan sindroma koroner akut/ acute coronary syndrome (ACS). Penggunaan antiplatelet khususnya klopidogrel berhubungan dengan perdarahan hebat pada pasien yang menjalani CABG, dan tindakan off pump tidak mengurangi risiko tersebut. Oleh karena itu, obat yang menginhibisi kerja reseptor P2Y12 pada platelet sebaiknya dihentikan sebelum menjalani CABG baik on pump maupun off pump. ${ }^{11}$

Rekomendasi umum untuk penghentian klopidogrel sebelum menjalani CABG adalah 5-7 hari, namun terdapat dua studi yang menyatakan bahwa penghentian selama 3 hari dapat menjadi alternatif untuk mengurangi risiko perdarahan. ${ }^{23,24}$

Respon terhadap terapi platelet cukup bervariasi. Pasien yang memiliki kadar reaktivitas platelet yang lebih tinggi setelah konsumsi obat berisiko lebih tinggimengalami kejadian iskemia rekuren. Sebanyak 30\% pasien resisten terhadap klopidogrel dan 10-12\% memiliki resistensi terhadap kombinasi aspirin dan klopidogrel. Tes terhadap responsivitas ADP secara point-of-care pada platelet mungkin dibutuhkan untuk mengidentifikasi pasien yang tidak responsif terhadap terapi platelet sehingga tidak perlu menunggu dan dapat langsung menjalani operasi. Tes tersebut dapat memperkirakan resistensi P2Y12 dengan spesifisitas $85 \%$. Terdapat tes yang lebih akurat namun tidak dapat dilakukan secara point-of-care. ${ }^{11}$

\section{Antifibrinolitik}

Terkait dengan penarikan masal aprotinin dari peredaran pada November 2007, saat ini hanya analog lisin/ asam epsilon-aminokaproat (EACA) dan asam traneksamat yang 
Tabel 1. Parameter klinis hipoksia pada pasien anemia normovolemik. ${ }^{10}$

\begin{tabular}{l}
\hline \multicolumn{1}{c}{ Parameter hipoksia pada anemia normovolemik } \\
\hline Gejala Kardiovaskular \\
Takikardia, hipotensi, hipotensi akut dengan sebab tidak jelas, \\
sesak napas \\
Gambaran EKG tipikal iskemia \\
Elevasi atau depresi segmen ST yang baru terjadi \\
Onset aritmia \\
Gangguan kontraktilitas lokal miokardium yang baru terjadi \\
Indikasi umum pelepasan $\quad$ O2 inadekuat melalui metode \\
invasif \\
Peningkatan ekstraksi $\mathrm{O}_{2}$ secara global $>50 \%$ \\
Penurunan ambilan $\mathrm{O}_{2}>10 \%$ nilai awal \\
Penurunan saturasi $\mathrm{O}_{2}$ vena campuran $<50 \%$ \\
Penurunan $\mathrm{pO}_{2}$ vena campuran $<32 \mathrm{mmHg}$ \\
Penurunan saturasi vena sentral $<60 \%$ \\
Asidosis laktat $($ laktat $>2 \mathrm{mmol} / \mathrm{L}+$ asidosis) \\
\hline
\end{tabular}

Tabel 2. Titik picu transfusi selama operasi jantung ${ }^{13}$

\begin{tabular}{|c|c|c|c|}
\hline Kondisi klinis & Titik picu & Anjuran Pedoman Praktik & Keterangan \\
\hline Periode pre-operasi & $\mathrm{Hb}<6 \mathrm{~g} / \mathrm{dl}$ & $\begin{array}{l}\text { Transfusi PRC untuk } \\
\text { menyelamatkan nyawa }\end{array}$ & $\begin{array}{l}\text { Transfusi tidak memperbaiki } \\
\text { transport oksigen saat } \mathrm{Hb}>10 \text { dan } \\
\text { tidak direkomendasi }\end{array}$ \\
\hline $\begin{array}{l}\text { Selama CPB dgn } \\
\text { hipotermia sedang }\end{array}$ & & Transfusi PRC rasional & $\begin{array}{l}\text { Indikasi transfusi } \mathrm{PRC} \text { jika } \mathrm{Hb}< \\
6 \mathrm{~g} / \mathrm{dl} \text { didukung faktor pasien, } \\
\text { kondisi klinis dan data } \\
\text { laboratorium }\end{array}$ \\
\hline $\begin{array}{l}\text { Tanpa risiko penurunan } \\
\text { hantaran oksigen otak }\end{array}$ & $\mathrm{Hb} \leq 6 \mathrm{~g} / \mathrm{dl}$ & & \\
\hline $\begin{array}{l}\text { Dengan risiko iskemi/ } \\
\text { cidera organ akhir yang } \\
\text { kritis }\end{array}$ & $\mathrm{Hb}<7 \mathrm{~g} / \mathrm{dl}$ & & \\
\hline Periode paska operasi & $\mathrm{Hb} \leq 7 \mathrm{~g} / \mathrm{dl}$ & Transfusi PRC diindikasikan & $\begin{array}{l}\text { Transfusi PRC mungkin } \\
\text { diperlukan pada pasien dengan } \\
\text { iskemi organ akhir kritis non } \\
\text { jantung dengan } \mathrm{Hb}>10 \mathrm{~g} / \mathrm{dl}\end{array}$ \\
\hline $\begin{array}{l}\text { Hemodilusi normovolemik } \\
\text { akut }\end{array}$ & & $\begin{array}{l}\text { Dapat digunakan sebagai } \\
\text { strategi konservasi darah } \\
\text { multimodal }\end{array}$ & $\begin{array}{l}\text { Kontraindikasi pada pasien tidak } \\
\text { stabil, terutama pada infark } \\
\text { miokard yang sedang berlangsung, } \\
\text { syok kardiogenik, anemia pre- } \\
\text { operatif, sepsis dan fraksi ejeksi } \\
\text { rendah }(<30 \%)\end{array}$ \\
\hline Residu darah pompa & & $\begin{array}{l}\text { Proses dengan pengendapan } \\
\text { dan reinfusi kembali ke } \\
\text { pasien }\end{array}$ & $\begin{array}{l}\text { Rasional menggunakan sisa darah } \\
\text { di pompa pada akhir operasi }\end{array}$ \\
\hline
\end{tabular}




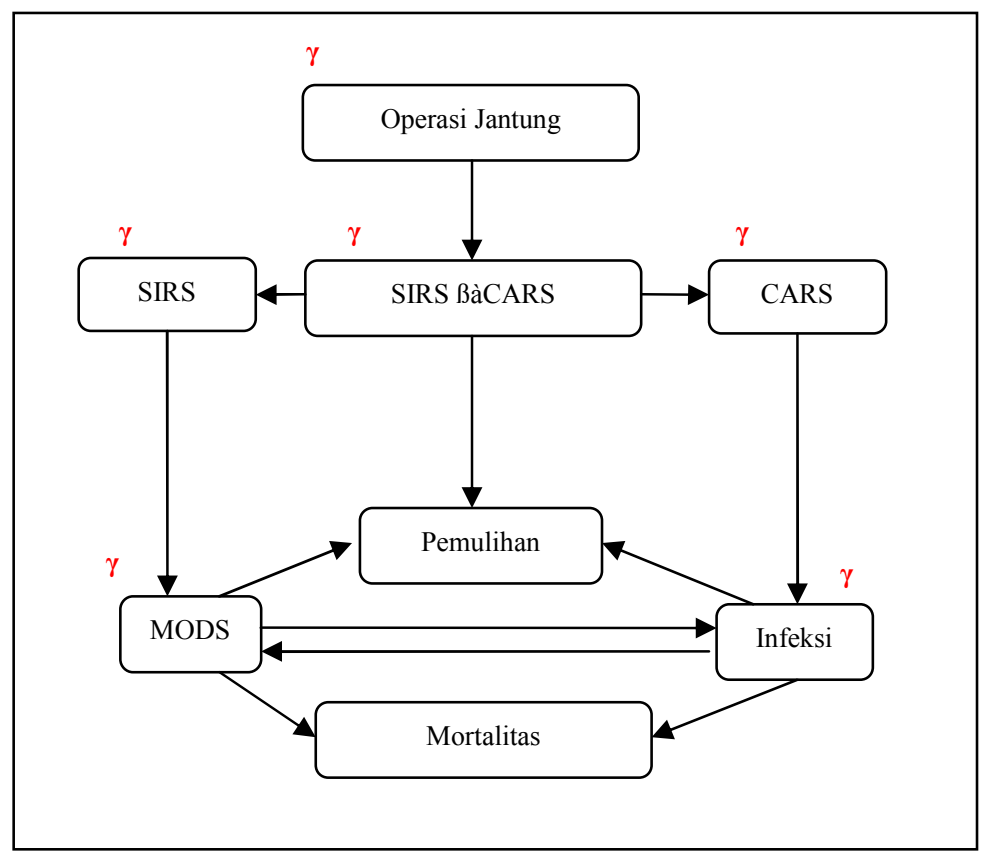

Gambar 1. Mekanisme transfusi darah dan komplikasi inflamasi setelah operasi jantung ${ }^{3}$ $\gamma$ : transfusi darah; CARS: Compensatory Anti-inflammatory Response Syndrome; SIRS: Systemic inflammatory Response Syndrome; MODS: Multi Organ Dysfunction Syndrome

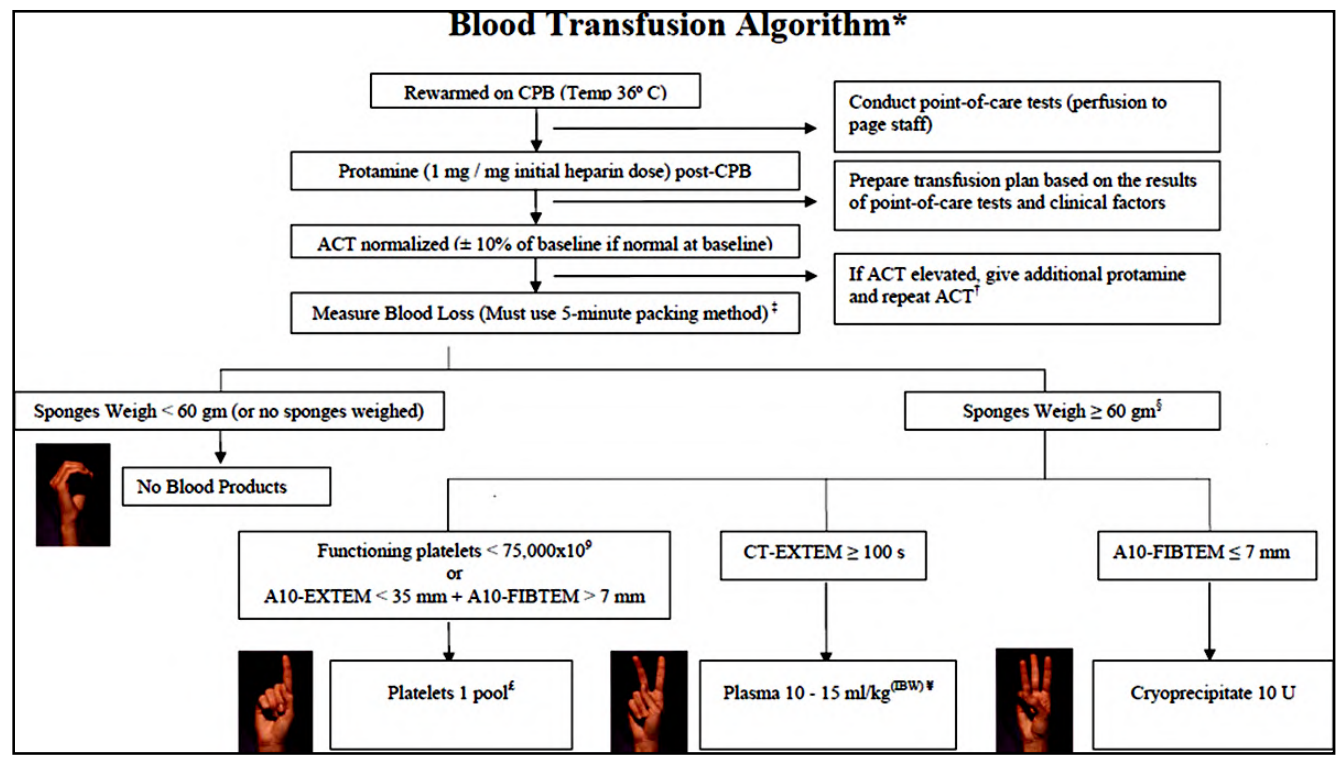

Gambar 2. Algoritma Transfusi

*Tidak berlaku untuk transfusi PRC yang berdasarkan level hemoglobin. ACT = activated clotting time; $\mathrm{CPB}=$ cardiopulmonary bypass $; \mathrm{PCC}=$ prothrombin complexconcentrate $; \mathrm{RBC}=$ red blood cell $; \mathrm{RV}=$ right ventricle 


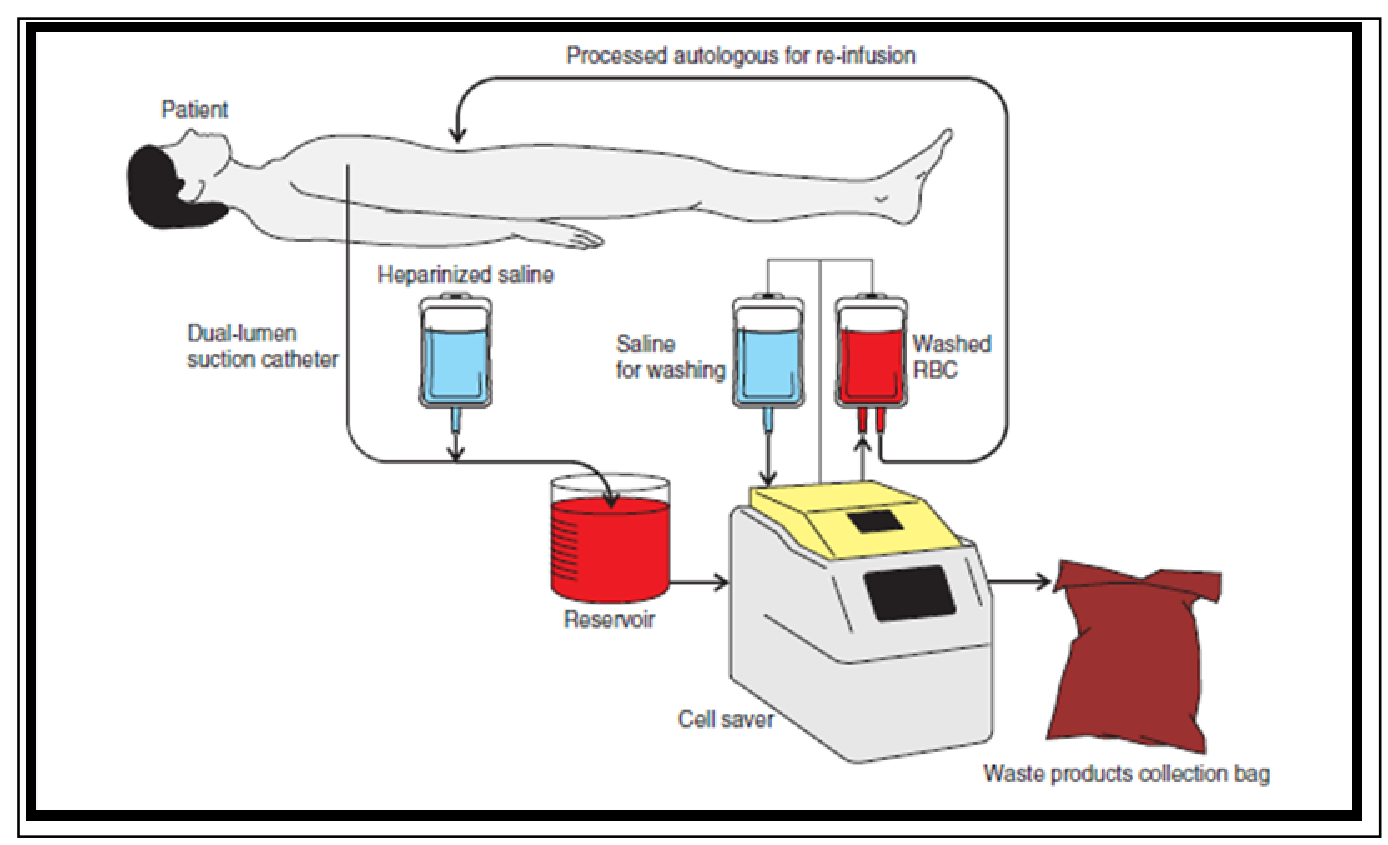

Gambar 3. Skema Intraoperative Blood Salvage ${ }^{18}$ 


\section{DAFTAR PUSTAKA}

1. Steidl S. The adverse effect of the cardiopulmonary bypass machine [Senior's thesis]. Lynchburg (VA): Liberty University; 2011.35p

2. D. Gavish, T. Ezri, A. Klepfish, A. A. Weinbroum, A. Izakso,n S. Evron. Perioperative blood transfusion: a brief review ofpros and cons .J Rom Anest Terap Int 2010; 17: 134-139

3. Bilgin YM, Watering LMG. Complications after cardiac surgery due to allogeneic blood transfusions. J Clin Exp Cardiolog 2013; S7: 005

4. Galas FRBG, ALmeida JP, Fukushima JT, Osawa EA, Nakamura RE, Silva CMPDC, et al. Blood ransfusion in cardiac surgery is a risk factor for increased hospital length of stay in adult patients.J Cardiothorac Surg 2013;8:54

5. Simon TL, Alverson DC, AuBuchon J, Cooper ES, DeChristopher PJ, Glenn $\mathrm{GC}$ et al. Practice parameter for the use of red blood cell transfusions: developed by the Red Blood Cell Administration Practice Guideline Development Task Force of the College American Pathologists. Arch Pathol Lab Med 1998; 122:130-8

6. Practice guidelines for perioperative blood transfusion and adjuvant therapies: an updated report by the American Society of Anesthesiologist Task Force on Perioperative Blood Transfusion and Adjuvant Therapies. Anesthesiology 2015; 122:241-75

7. Esper SA, Subramaniam K, Tanaka KA. Pathophysiology of cardiopulmonary bypass: current strategies for the prevention and treatment of anemia, coagulopathy, and organ dysfunction.Semin Cardiothorac Vasc
Anesth 2014;18:161-76

8. Levy JH. Kessler CM (editor) The effects of cardiopulmonary bypass on coagulation. Clin Adv Hematol Oncol 2013;11:589-91

9. Wilkinson KL, Brunskill SJ, Doree C, Trivella M, Gill R, Murphy MF.Red cell transfusion management for patients undergoing cardiac surgery for congenital heart disease.Cochrane Database Syst Rev 2014;2:CD009752

10.Liumbruno GM, Bennardello F, Lattanzio A, Piccoli P, Rossetti G. Recommendations for the transfusion management of patients in the perioperative period. I. The pre-operative period. Blood Transfus. 2011; 9: 19-40

11.Ferraris et al. 2011 Update of The Society of Thoracic Surgeons and the Society of Cardiovascular Anesthesiologists Blood Conservation Clinical Practice Guidelines. The Annals of Thoracic Surgery 2011;91:944-82

12.Farland JG. Perioperative blood transfusions: indications and options. Chest 1999; 115: (suppl)113S-21S

13.Mangu HR, Samantaray A, Anakapalli M. Blood transfusion practices in cardiac anaesthesia. Indian $\mathrm{J}$ Anaesth 2014;58:616-21

14. Sharma S, Sharma P, Tyler LN. Transfusion of blood and blood products: indication and complication. Am Fam Physician 2011;83(6):719-24

15.Rohde JM, Dimcheff DE, Blumberg N, Saint S, Langa KM, Kuhn L, et al. Health care-associated infection after red blood cell transfusion: A systematic review and meta-analysis.JAMA 2014;311:1317-26

16.Karkouti K. Transfusion and Risk of Acute Kidney Injury in Cardiac 
Surgery. Br J Anaesth 2012;109 (Suppl 1):i29-i38

17.Tjutanto R, Wuwungan AA, Lalenoh HJ. Autotransfusi perioperatif. Jurnal Biomedik 2013;5:17-20

18.Ashworth A, Klein AA. Cell salvage as part of a blood conservation strategy in anaesthesia.Br J Anaesth 2010;105:40116

19.Engels GE, van Klarenbosch J, Gu YJ, van Oeveren W, de Vries AJ. Intraoperative Cell Salvage during Cardiac Surgery is Assoiated with Reduced Postoperative Lung Injury. Interact Cardiovasc Thorac Surg. 2016;22:298-304

20.Liumbruno GM, Bennardello $F$, Lattanzio A, Piccoli P, Rossetti G. Recommendations for the transfusion management of patients in the perioperative period. III. The post-operative period.Blood Transfus. 2011;9:320-35

21. Weltert L, Rondinelli B, Bello R, Falco $\mathrm{M}$, Bellisario A, Maselli D, et al. A single dose of erythropoietin reduces perioperative transfusions in cardiac surgery: results of a prospective single blind randomized controlled trial. Transfusion 2015;55:1644-54

22.Cladellas M, Farré N, Comín-Colet J, Gómez M, Meroño O, Bosch MA, et al. Effects of preoperative intravenous erythropoietin plus iron on outcome in anemic patients after cardiac valve replacement. Am J Cardiol 2012;110:1021-6

23.Haydar AA, Abchee AB, El-Hajj II, Hujairi NMA, Tfaili AS,Hatoum T, et al. Bleeding post coronary artery bypass surgery, clopidogrel - cure of culprit? Leb Med J 2006; 54: 11-16

24.Maltais S, Perrault LP, Do QB. Effect of clopidogrel on bleeding and transfusions after off-pump coronary artery bypass graft surgery: impact of discontinuation prior to surgery. Eur $\mathrm{J}$ Cardiothorac Surg 2008;34:127-31

25.Liumbruno GM, Bennardello F, Lattanzio A, Piccoli P, Rossetti G. Recommendations for the transfusion management of patients in the perioperative period. II. The intra-operative period. Blood Transfus 2011;9:189-217 